\title{
The Role of the State Againts the Fulfillment of Human Rights of Person with Disabilitas in Indonesia
}

\author{
Yohanes Suhardin ${ }^{1}$, AL. Sentot Sudarwanto ${ }^{2}$ \\ \{ johnsuhardin@gmail.com ${ }^{1}$ alsentotsudarwanto@staff.uns.ac.id ${ }^{2}$ \} \\ St. Thomas Catholic University of Medan ${ }^{1}$, University of Sebelas Maret, Surakarta ${ }^{2}$
}

\begin{abstract}
Modes of transportation and road facilities as well as security in traffic area the basic human rights of persons with disabilities, especially wheelchair users. In developed countries, transportation modes such as buses have been designed for facilitate wheelchair usesr by bus. So the streets are already marked for wheelchair user. In particular the human rights of persons with disabilities are guaranteed by the law of Republic of Indonesia number 39 of 1999 on human rights. But in really not yet. All modes of transportation such as city buses and intercity buses and intercity buses are designed to facilitate wheelchair users. Even if there is very limited. Even if there is very limited. Should the state through its apparatus be at the forefront of the fulfillment of the human rights of disabled people especially the wheelchair users in traffic in Indonesia. This is done not only by making laws about people with disabilities but also ensuring their rights are well done.
\end{abstract}

Keywords: The Role of The State, Human Rights, Persons with Disabilities.

\section{Introduction}

The role of the state in protecting vulnerable groups is still a problem in Indonesia. Vulnerable groups are parts of society that are either consciously or not and directly or indirectly, are often marginalized to enjoy their rights. The marginalization of these vulnerable groups is mainly because they often receive unequal and discriminated treatment.

They often lose access to be able to participate and contribute, as well as in determining and maintaining their existence. Not only that, they also often have to lose their rights, which causes them to face various obstacles or limitations to enjoy a good standard of living. Meanwhile, those who can be categorized as vulnerable groups include the elderly, children, the poor, people with disabilities, women (especially pregnant women), refugees, internally displaced people, minorities, migrant workers and indigenous people .

Based on the Sakernas 2017 data the national working age disability population is $21,930,529$ people. In addition, according to Data from the National Commission on Human Rights (Komnas HAM), there are tens of millions of people with disabilities in Indonesia whose fate is still marginalized. Need concrete care and action from the government, community, and related parties so that they can enjoy their rights. ${ }^{1}$ The United Nations (UN) estimates that there are around 600 million people with disabilities worldwide. Of that total 82

${ }^{1}$ Komisi Nasional Hak Asasi Manusia (Komnas HAM), Potret Buram Hak Asasi Manusia Indonesia (Kumpulan Tulisan Rubrik Utama Buletin Wacana HAM 2015), Jakarta, hlm. 53. 
percent live in rural areas in developing countries and about 70 percent of the 500 million people are estimated to have very limited access or do not have access to the services they need. $^{2}$

Related to being able to enjoy their rights, in terms of getting access to public facilities, for example road facilities in urban areas have not been specifically designed for people with disabilities. Road facilities generally in Indonesia are only for general citizens who do not have physical disabilities such as people with disabilities or disabilities. Persons with disabilities do not get adequate public facilities. Persons with disabilities often have difficulty using city transportation which is not equipped with special facilities for them and there are no pedestrTian bridges designed specifically for persons with disabilities. ${ }^{3}$ In the construction of frequent public facilities from architects, urban planning, landscapes experts, developers, building owners, even government officials still do not care about accessibility for persons with disabilities.

\section{Literature Review}

The word disability is a new term in place of the word disabled. In various Indonesian dictionaries, the term disability is not found. But the word that means the same is the word "disability" which means damage to a person's body, both body and limb, both physical loss, abnormal form and reduced function due to innate birth or due to diseases and other disorders that arise real to carry out life's tasks and adjustments. ${ }^{4}$

According to the World Health Organization (WHO), disability is an inability to carry out certain activities / activities as normal people do, which is caused by conditions of loss or disability both psychological, physiological and structural abnormalities or anatomical functions. ${ }^{5}$ In other words, disability is the inability to carry out certain activities / activities as normal people are caused by conditions of impairment related to age and society.

In the past the term disability was known as a disabled person. The Law of the Republic of Indonesia Number 19 of 2011 concerning the Ratification of the Convention on the Rights of Persons with Disabilities (Convention on the Rights of Persons with Disabilities) no longer uses the term disabled, replaced by persons with disabilities. Based on the convention, people with disabilities are people who have physical, mental, intellectual, or sensory limitations for a long time, where when they are faced with various obstacles, this can make it difficult for them to participate fully and effectively in society based on equal rights.

\subsection{Rights of Persons With Disabilities}

The regulation on disability in the 1945 Constitution of the Republic of Indonesia is contained in Article $28 \mathrm{H}$ paragraph (2) which states "every person has the right to get special

${ }^{2}$ Ibid., hlm. 54.

${ }^{3}$ Kompas, Dukungan Kemandirian Penyandang Disabilitas, Kamis, 31 Mei 2018.

${ }^{4}$ Departemen Pendidikan Nasional, Kamus Besar Bahasa Indonesia, Edisi Keempat, Penerbit PT Gramedia Pustaka Utama, Jakarta, 2008, hlm. 233.

5 https://www.scribed.com, Marjuki, Penyandang Cacat Berdasarkan Klasifikasi International Classification of Functioning for Disabilitas and Health (IFC), Makalah Kepala Badan Pendidikan dan Penelitian Kesejahteraan Sosial Departemen Sosial Republik Indonesia, diakses, Kamis, 23 Agustus 2018. 
facilities and treatment to obtain equal opportunities and benefits in order to achieve equality and justice. In addition, it is also regulated in Article 28I paragraph (2) which states: "every person has the right to be free from discriminatory treatment on any basis and has the right to protection from such discriminatory treatment.

In addition to being regulated in the 1945 Constitution of the Republic of Indonesia, disability is also regulated in Article 5 paragraph (3) of Law Number 39 of 1999 concerning Human Rights which states that "everyone who is a vulnerable group is entitled to more treatment and protection with regard to its specificity. In the explanation of the paragraph stated that what is meant by "vulnerable community groups" include elderly people, poor children, pregnant women and people with disabilities.

Based on these provisions, people with disabilities are one of the elements of vulnerable community groups. In its development, the term commonly used by people is disabled. Up to now, Indonesia has twice enacted a special law on Persons with Disabilities. First; Law Number 4 of 1997 concerning Disabled Persons. Second; Law Number 8 of 2016 concerning Disabled Persons. In the law, it is stated that persons with disabilities are those who experience physical, intellectual, mental and / or sensory limitations for a long time in interacting with the environment to experience obstacles and difficulties in participating fully and effectively with other citizens based on similarities right.

Persons with disabilities have the right to life; free of stigma; privacy; justice and legal protection; education; employment, entrepreneurship, and cooperatives; health; political; religious; sports; culture and tourism; social welfare; accessibility; public service; protection from disasters; habilitation and rehabilitation; concession; data collection; live independently and be involved in the community; express, communicate, and obtain information; move places and citizenship; and free from acts of discrimination, neglect, torture and exploitation (Article 5 paragraph 1).

In addition to being regulated in various national legislation concerning persons with disabilities, it is also regulated in the International Convention. Among other things, the Convention on the Rights of Persons with Disabilities and its Optional Protocol (A / RES / 61/106) was adopted on December 13, 2006 at UN Headquarters in New York, and was opened for signature on March 30, 2007. There were 82 signatories to the convention, 44 signatories Optional Protocol, and 1 convention ratification.

The Convention on the Rights of Persons with Disabilities aims to promote, protect and guarantee the full and equal enjoyment of all human rights and fundamental freedoms by all persons with disabilities and to promote respect for the dignity attached to them. Persons with disabilities include those who have long-term physical, mental, intellectual or sensory damage that in interaction with various barriers can hinder their participation in society and be full and effective based on the principle of equality. ${ }^{6}$

Conventions related to disability, discrimination on the basis of disability is when a person is excluded, obstructed from doing something or treated differently because of the person's disability, in a way that prevents the person from exercising or enjoying all human rights and freedoms as well as other people. This includes rejection of adequate accommodation for that person.

The general principles in this convention are respect for the dignity of individuals, autonomy and independence of individuals; non-discrimination; full and effective participation and inclusion / participation in the community; respect for differences and

${ }^{6}$ Bambang Sutiyoso, Konsepsi Hak Asasi Manusia dan Implementasinya di Indonesia, (Jakarta: UII Press, 2002), hlm. 23. 
acceptance of persons with disabilities as part of humanity and human diversity; equal opportunity; accessibility; equality between men and women; respect for the capacity of children with disabilities and their right to maintain their identity.

\subsection{Country Role}

The state which in this case is the government, especially the regional and municipal governments has the role of fulfilling and providing comfortable and safe pedestrian facilities for people, especially persons with disabilities. Relevant to this, as Kleinfeld points out, that a function of the state is to protect the ownership and safety of citizens from violations and attacks by other citizens. ${ }^{7}$

The safety of citizens, especially people with disabilities, should be the government's attention. Therefore, the role of the government in fulfilling social rights for diffables, one of which is the fulfillment of formal legal rights for mobility. The police and other related parties, that driving safely, do not endanger the safety of other road users.

In addition, in the new discourse of thinking about democracy, one of the important points is that democracy must give a place to the existence of marginal groups in society so that they can articulate their existence in the system and structure of society. Included in groups that are called marginal include persons with disabilities. ${ }^{8}$

Solo is a city that is often referred to as a haven for people with disabilities because it is disability friendly and has concrete programs to build accessibility for people with disabilities. This can be used as a serious basis for the concern of the central government regarding disability issues in Indonesia. Solo is a city that has a complete sidewalk with block guiding for blind people. Solo is also one of the cities that pioneered the drafting of the Disability Regional Regulation.

At present, various public facilities such as transportation in Jakarta and other big cities are still processing efforts to establish accessibility to the rights of persons with disabilities. Among other things, accessibility in public spaces such as sidewalks or roads in parks that have ramps, thus facilitating mobility of wheelchair users. All of these processes require substantial support from local, central and local communities. Be it policy support, regulation, funding or socio-cultural support from various community groups. Disability affairs are a shared responsibility between the government and society.

However, considering that Indonesia is a welfare state as stated in the fourth paragraph of the Preamble of the 1945 Constitution of the Republic of Indonesia, Article 27 paragraph (2), Articles 33 and 34, the state is required to be responsible for fulfilling basic needs, overcoming poverty and guarantee work for all of its people. For people with special needs such as persons with disabilities, supporting facilities must be provided to fulfill the rights of persons with disabilities.

Article 2 of Law No. 39 of 1999 concerning Human Rights states that the State of the Republic of Indonesia recognizes and upholds human rights and basic human freedoms as a right inherent in and inseparable from human beings, which must be protected, respected and enforced for the enhancement of human dignity, welfare happiness and intelligence and justice.

\footnotetext{
7 Tio Tegar Wicaksono, Tanggung Jawab Negara dalam Rangka Perlindungan dan Pemenuhan Hak Penyandang Disabilitas, vivajusticia.law.ugm.ac.id, diakses pada hari Jumat, 24 Agustus 2018.

${ }^{8}$ PresidenRI.go.id, Model Pemenuhan Hak Penyandang Disabilitas Kota Solo, diakses pada hari Jumat, 24 Agustus 2018.
} 
In Indonesia there is what is known as the Road Safety for Humanity, but facilities related to people with disabilities have not received much attention. There are three facilities for people with disabilities on the sidewalk which until now have not been fulfilled, even many do not understand the function and existence. ${ }^{9}$

First is Guiding Block. This facility acts as a guiding path and guidance for people with disabilities, especially blind people, using yellow tiles with straight lines and round textures. At present the facility has started on several sidewalks in Jakarta, but it does not work according to its function. Second is Ramp. The function of Ramp is as a substitute feature of stairs that is usually used by the elderly or persons with disabilities to go to higher places or when going to public transportation such as buses and trains. Third is Portas $\mathrm{S}$ which is useful to protect wheelchair users. As the name implies, the portal form is designed like the letter $\mathrm{S}$ which is made of stainless and is located at the ends of the sidewalk. In Jakarta, this facility is very minimal.

Therefore, the state then makes legislation in order to realize the basic needs of citizens. Moreover, Indonesia is categorized as a welfare state as implied in the Preamble of the 1945 Constitution of the Republic of Indonesia. Characteristics of a welfare state that does not hold the prices of facilities that can be used by the community, but the state is obliged to provide various services including health services, education, road construction and procurement traffic facilities, postal and telecommunications, radio and television facilities, various social services, creating or providing assistance to cultural institutions; and especially in modern countries, various ways to develop the nation's economic capacity with the aim that all members of society, at a minimum, can live free from excessive poverty and economic dependence.

The state should guarantee the fulfillment of the human rights of persons with disabilities in traffic, namely traffic security and road transportation. According to Article 30 Article 1 of Law No. 22 of 2009 concerning Road Traffic and Transportation, traffic safety and road transportation is a condition of liberation of every person, property, and / or vehicle from interference with acts of resistance, and / or fear in traffic. Furthermore, in point 31 of Article 1 of the law, it is stated that traffic and road transport safety is a condition of avoidance of everyone from the risk of accidents during traffic caused by humans, vehicles, roads and / or the environment. In this connection, traffic order and road transportation are a traffic condition that takes place regularly in accordance with the rights and obligations of each road user.

Part Six Support Facilities Article 45 paragraph (1) of Law No. 22 of 2009 concerning Road Traffic and Transportation states that supporting facilities for the operation of Road Traffic and Transportation include sidewalks; Bike Lane; pedestrian crossings; stop; and / or special facilities for people with disabilities and elderly people.

Provision of supporting facilities as referred to in paragraph (1) shall be carried out by the government for national roads; provincial government for provincial roads; District government for district and village roads; City government for city roads; and toll road business entities for toll roads.

Special treatment for people with disabilities, elderly people, children, pregnant women and sick people. Part one Special Scope of Treatment. Article 242 of the Act is stated:

(1) The Government, Regional Government and / or Public Transportation Company are obliged to give special treatment in the field of Traffic and Road Transportation to people with disabilities, elderly people, children, pregnant women and sick people. What is meant by special treatment is the provision of facilities, in the form of general physical and non-

${ }^{9}$ https://megapolitan.Kompas.com, diakses, Jumat, 24 Agustus 2018. 
physical facilities and infrastructure, as well as information needed for people with disabilities, elderly people, children, pregnant women, and sick people to obtain equal opportunities.

(2) Special treatment as referred to in paragraph (1) includes Accessibility; service priority; and service facilities. The priority of service is the prioritization of the provision of special services.

Law No. 39 of 1999 concerning Human Rights implicitly requires the state to play a role in realizing the rights of persons with disabilities. In the international convention the rights of persons with disabilities states that countries need to ensure that persons with disabilities enjoy all human rights and fundamental freedoms without discrimination in any form due to disability. In doing this, countries agree to implement rights at the convention; remove or change laws, policies, or ways that discriminate against persons with disabilities; pay attention to the rights of persons with disabilities in policies and programs; ensuring that government officials act in line with the obligations at the convention; eliminate discrimination on the basis of disability caused by any person or organization; carry out or encourage research and development of goods, services and facilities that can be accessed by persons with disabilities, and at a lower cost; provide easily accessible information about new technologies that can help people with disabilities, assistive devices and mobility devices; encourage the training of the rights of persons with disabilities for people who work with people with disabilities; carry out the parts of the Convention that are immediately applicable in accordance with the international standard, and pay attention to the available resources, and gradually carry out the parts related to economic, social and cultural rights; and ensure that persons with disabilities, including children, can express their opinions on the way the Convention is implemented, through the organizations that represent them.

\section{Conclusion}

Normally the juridical role of the state in realizing the rights of persons with disabilities as part of human rights is adequate. However, at the level of implementation it is still very weak. Public facilities that support the fulfillment of the rights of persons with disabilities are not well available, especially the rights of persons with disabilities in traffic. Even though the Road and Traffic Transport Law has regulated the rights of persons with disabilities in traffic, but in reality, the road conditions of big cities in Indonesia are not yet possible for persons with disabilities to travel safely and safely. There are no special roads available for people with disabilities, city buses are not designed to make it easier for people with disabilities to use them safely and safely. Likewise, special crossings for people with disabilities on the Railway track in big cities are not yet available.

The various problems faced by persons with disabilities must be immediately resolved if the Indonesian people are committed to upholding human rights for all. This is done by making and or improving policies so that they can guarantee the rights of persons with disabilities, help create social conditions that enable people with disabilities to take part in development, and eliminate all discriminatory actions. 


\section{References}

[1]. Departemen Pendidikan Nasional, Kamus Besar Bahasa Indonesia, Edisi Keempat, (Jakarta: Penerbit PT Gramedia Pustaka Utama, 2008).

[2]. Https://megapolitan.Kompas.com, diakses, Jumat, 24 Agustus 2018.

[3]. Komisi Nasional Hak Asasi Manusia (Komnas HAM), Potret Buram Hak Asasi Manusia Indonesia (Kumpulan Tulisan Rubrik Utama Buletin Wacana HAM), (Jakarta: 2005).

[4]. Kompas, Dukungan Kemandirian Penyandang Disabilitas, Kamis, 31 Mei 2018.

[5]. Ohoitimur, Yong, Teori Etika tentang Hukuman Legal, (Jakarta: Gramedia Pustaka Utama, 1997).

[6]. Sutiyoso, Bambang, Konsepsi Hak Asasi Manusia dan Implementasinya di Indonesia, (Jakarta: UII Press, 2002).

[7]. Rahardjo, Satjipto, Hukum Progresif, Sebuah Sintesa Hukum Indonesia, (Yogyakarta: Genta Publishing, 2009).

[8]. Suhardin, Yohanes, Hukum dan Hak Asasi Manusia (Suatu Pengantar), (Semarang: Badan Penerbit Universitas Diponegoro, 2011).

[9]. Suhardin, Yohanes, Rudy Haposan Siahaan, Pengaruh Budaya Sistem Hukum Asing Terhadap Negara Hukum Kesejahteraan Indonesia, (Medan: PT. Sofmedia, 2014).

[10]. Tio Tegar Wicaksono, Tanggung Jawab Negara dalam Rangka Perlindungan dan Pemenuhan Hak Penyandang Disabilitas, vivajusticia.law.ugm.ac.id, diakses pada hari jumat, 31 Agustus 2018.

[11]. Undang-Undang Dasar Negara Republik Indonesia Tahun 1945.

[12]. Undang-Undang Negara Republik Indonesia Nomor 39 Tahun 1999 tentang Hak Asasi Manusia.

[13]. Undang-Undang Negara Republik Indonesia Nomor 22 Tahun 2009 tentang Lalu Lintas dan Angkutan Jalan.

[14]. Undang-Undang Negara Republik Indonesia Nomor 19 Tahun 2011 tentang Pengesahan Convention on the Rights of Persons With Disabilitas (Konvensi mengenai Hak-Hak Penyandang Disabilitas)

[15]. Peraturan Pemerintah No. 74 Tahun 2014 tentang Angkutan Jalan.

[16]. Peraturan Pemerintah No. 79 Tahun 2013 tentang Jaringan Lalu Lintas dan Angkutan Jalan. 